\title{
PENGGUNAAN PRINSIP KERJA SAMA GRICE DALAM ACARA HITAM PUTIH "PAHLAWAN VETERAN INDONESIA"
}

\author{
Farhanah Fatin ${ }^{1)}$ \\ ${ }^{1}$ Pendidikan Bahasa dan Sastra Indonesia, Fakultas Ilmu Tarbiyah dan Pendidikan, Universitas Islam Negeri Syarif \\ Hidayatullah Jakarta, Jl. Ir. H. Djuanda No.95, Ciputat, Tangerang Selatan, Banten 15412, Indonesia. \\ E-mail: farhanah.fatin17@mhs.uinjkt.ac.id
}

\begin{abstract}
Abstrak
Penelitian ini bertujuan untuk mengetahui prinsip-prinsip kerja sama grice. Dan cara pemakaian kerja sama grice pada acara Hitam Putih "Pahlawan Veteran Indonesia", acara yang dipandu oleh Deddy Corbuzier dan Chika Jessica bersama dengan para veteran serta Reza Rahadian yang menjadi salah satu bintang tamu di acara Hitam Putih "Pahlawan Veteran Indonesia". Metode yang dilakukan untuk merampungkan penelitian ini adalah menggunakan metode deskriptif kualitatif. Peneliti mengumpulkan data menggunakan metode simak dan menulis, yaitu dengan menyimak video talk show Hitam Putih "Pahlawan Veteran Indonesia" dan menulis kembali apa yang telah disimak dari video tersebut Hasil dari penelitian ini adalah untuk mengetahui bagaimana cara seorang pembawa acara menggunakan prinsip kerja sama grice yang di dalamnya terdapat maksim kuantitas, maksim kualitas, maksim relasi, dan maksim cara, begitupun sebaliknya berbicara seorang tamu dengan pembawa acara.
\end{abstract}

Kata Kunci: Prinsip Kerja Sama; Maksim Kuantitas dan Kualitas; Acara Hitam Putih.

\begin{abstract}
This research aims to knowthe principles of grice cooperation. And how to use grice's cooperation in the Black and White event "Pahlawan Veteran Indonesia", an event hosted by Deddy Corbuzier and Chika Jessica together with veterans and Reza Rahadian who was one of the guest stars at the Black and White event "Pahlawan Veteran Indonesia". The method used to complete this research is to use a qualitative descriptive method. The researcher collected data using the listening and writing method, namely by listening to the Black and White video talk show "Pahlawan Veteran Indonesia" and rewriting what he had listened to from the video. The results of this study were to find out how a host uses the grice principle of cooperation. in it there is a maxim of quantity, a maxim of quality, a maxim of relations, and a maxim of manner, and vice versa when talking to a guest with the host.
\end{abstract}

Keywords: The Principle of Cooperation; Maxim of Quantity and Quality; event Black and White Show.

\section{PENDAhuluan}

Pada kehidupan, kita tidak terlepas dari suatu bahasa. Bahasa adalah suatu hal yang sudah terikat dalam kehidupan masyarakat. Seperti yang dikemukakan oleh (Chaer, 2009) bahwa "Bahasa adalah sistem lambang bunyi yang arbitrer yang digunakan oleh anggota kelompok sosial untuk bekerja sama, berkomunikasi, dan mengidentifikasikan diri”. Ini artinya, bahwa dalam kehidupan sosial, kita tidak terlepas dari kegiatan berbahasa, khususnya dalam kegiatan berkomunikasi atau bertutur secara lisan.

$$
\text { Adapun (Damayanti, }
$$
mengemukakan bahwa bahasa merupakan instrument penting untuk mengkoordinir tindak komunikatif, dalam rangka mencapai tujuan sosial bersama. Secara tidak langsung bahasa itu merupakan sebagai instrument atau alat dalam berkomunikasi antar masyarakat. Memang pada dasarnya manusia merupakan makhluk sosial yang selalu menjadikan bahasa sebagai alat komunikasi (Fatimah et al., 2018).

(Cliford, 1989) menjelaskan bahwa bahasa yang santun merupakan bahasa yang dipergunakan oleh masyarakat dengan memperhatikan hubungan sosial antar pembicara dan penyimak serta bentuk status dari keakraban. Status kehidupan di masyarakat ditentukan oleh kekayaan, keturunan, pendidikan, pekerjaan, usia, hubungan darah, dan kebangsaan antara satu dengan yang lainnya. Bagi Greetz Cliford, kesantunan itu adalah kesesuaian dengan status pengguna bahasa sehingga efeknya menimbulkan keakraban antara penutur dan pendengar. 
Bahkan lebih dari itu, bahasa santun menjadi ciri status sosial masyarakat penggunanya.

Dari segi moral, (Suryalaga, 2009) melihat bahwa setiap bahasa kesatuan untuk saling hormat menghormati sesama manusia. Santun berbahasa artinya akhlak menggunakan bahasa dalam kehidupan sehari-hari, atau dalam pergaulan bersama dengan teman sebaya, kakak, orang tua, guru, pejabat, dan santun berbahasa sangat berkaitan erat dengan rasa berbahasa. Adapun yang menjadi sumber santun berbahasa adalah; umur, naluri, nurani, agama, keluarga, lingkungan, adat istiadat, pengalaman, kebiasaan, dan peradaban bangsa (Sauri, 2002)

Masyarakat sebagai kelompok manusia membentuk dan mewujudkan suatu lingkungan yang dikehendaki oleh para anggotanya. Nilai dan norma yang berlaku di dalamnya tergantung kepada kesepakatan yang diberlakukan dalam masyarakat itu. Manusia, interaksi sosial, agama, dan alam sekitarnya merupakan unsur-unsur yang saling pengaruhi dalam membentuk norma. Manusia sebagai makhluk moral memiliki potensi dalam dirinya untuk cenderung kepada hal-hal yang baik. Interaksi sosial antar manusia mewujudkan kesepakatan norma yang dipegang dan digunakan bersama sebagai acuan normative sebagai sesuatu yang baik dan diterima secara sosial. Demikian pula agama yang merupakan keyakinan tertinggi memberikan sumber nilai dan norma ilahiyah yang digunakan dalam dimensi pribadi maupun sosial (Sauri, 2002).

Talk show adalah sebuah program televisi atau radio yang di dalamnya terdapat seseorang atau group berkumpul bersama untuk mendiskusikan berbagai hal topik dengan suasana santai tapi serius, yang dipandu oleh moderator. Kadangkala talk show menghadirkan tamu berkelompok yang ingin mempelajari berbagai pengalaman hebat. Tamu yang diundang biasanya terdiri dari orangorang yang telah mempelajari atau memiliki pengalaman luas yang terkait dengan isu yang sedang diperbincangkan oleh acara talk show, biasanya dapat menerima telepon dari para pendengar atau penonton yang berada di rumah, mobil, ataupun di tempat lain (Wulandari, 2016).

Dalam suatu acara talk show tentu banyak bahasa yang digunakan, acara talk show tidak ada batasan untuk memakai bahasa. Acara talk show tentu saja ada pembawa acara atau penutur dan ada kawan tutur yang saat berbicara bersifat formal. Seperti yang telah dijelaskan di atas, setiap acara talk show akan memakai bahasa sehari-hari dan ada juga yang memakai bahasa formal karena melihat jarak sosial antara penutur dan kawan tutur jauh.

Dari penjelasan di atas, peneliti akan meneliti tentang bagaimana cara bertutur di dalam acara talk show Hitam Putih "Pahlawan Veteran Indonesia". Meneliti pemakaian bahasa yang benar pada acara tersebut, ada keunikan tersendiri di dalam acara Hitam Putih di mana di dalamnya berbicara tentang perjuangan veteran pada zaman sebelum merdeka, keluh kesah yang dirasakan para veteran sekarang. Pembawa acara mendatangkan para veteran karena perjuangan para veteran patut dicontoh untuk para penonton yang hadir.

Tujuan dari penelitian ini adalah untuk melihat 1) penggunaan prinsip kerja sama grice dalam acara talk show Hitam Putih "Pahlawan Veteran Indonesia", 2) mendefinisikan kerja sama grice dengan data yang sudah di dapat dan dikaitkan dengan teori kerja sama grice, 3) dikaitkan dengan jarak sosial budaya antara penutur dan kawan tutur.

\section{METODE PENELITIAN}

Metode yang dilakukan untuk merampungkan penelitian adalah menggunakan metode deskriptif kualitatif. Sebagaimana diketahui penelitian kualitatif merupakan aktivitas ilmiah untuk mengumpulkan data secara sistematik, mengurutkannya sesuai kategori tertentu, mendeskripsikan dan menginterpretasikan data yang diperoleh dari wawancara atau percakapan biasa, observasi, dan dokumentasi. Datanya bisa berupa kata, gambar, foto,catatancatatan rapat, dan sebagainya (Manab, 2015) 
Dalam penelitian ini peneliti mengumpul data menggunakan metode simak dan menulis, yaitu dengan menyimak video talk show Hitam Putih "Pahlawan Veteran Indonesia" dan menulis kembali apa yang telah disimak dari video tersebut. Video yang berdurasi 1:06:21 menit diambil dari aplikasi youtube.

\section{HASIL DAN PEMBAHASAN}

Di dalam Prinsip Kerja Sama Grice sesungguhnya hendak ditegaskan bahwa dalam aktivitas berbahasa harus ada semacam kerja sama antara pihak penutur dan mitra tutur, atau antara penyapa dan pesapa, atau antara pihak 'utterrer' dan 'interpreter'. Di dalam praktik bertutur sapa sangat dimungkinkan ada penyimpangan, tetapi harus selalu dicatat bahwa penyimpangan yang terjadi harus selalu bermaksud, atau dalam istilah harus selalu memiliki tujuan (goal-oriented). Dalam istilah (Wijana, 1996), penyimpangan-penyimpangan dalam praktik berkomunikasi yang memerantikan bahasa itu dimungkinkan terjadi karena ada implikasi-implikasi tertentu. Jadi, kalau implikasi dan/atau maksud dari penyimpangan itu tidak dapat ada, itu artinya tidak ada kerja sama di antara penutur dan mitra tutur. Kerja sama di antara pihak-pihak yang terlibat dalam pertuturan itu demi berjalannya aktivitas berbahasa dan bertutur sapa dengan baik dalam praktik berkomunikasi. Itulah sesungguhnya yang dimaksud dengan Prinsip Kerja Sama sebagaimana yang disampaikan Grice untuk dapat terpenuhinya dengan baik maksim-maksim percakapan atau 'conversational maxims' (Rahardi, 2016). Berikut setiap maksim di dalam Kerja Sama Grice:

\section{a. Maksim Kualitas}

Maksim kualitas ditegaskan bahwa penutur maupun mitra tutur, ('utterer' maupun 'interpreter') di dalam sebuah pertuturan haruslah mengatakan sesuatu yang sebenarnya, sesuatu yang sesuai dengan kenyataannya. Apabila seserang tidak berbicara sesuai dengan seharusnya, alias tidak menyampaikan dengan sesungguhnya, harus dikatakan bahwa tuturan itu tidak sejalan dengan maksim kualitas sebagaimana yang disampaikan Grice. Misalnya saja dengan mengatakan, "Anda dapat nilai berapa untuk ulangan tadi, Vendi?", Maka, jawaban yang dianggap sejalan dengan maksim kualitas itu adalah, "Delapan, Bu!" Jadi, pertanyaan yang disampaikan dengan kata Tanya 'berapa', misalnya saja, jawabnya pastilah menunjuk pada 'angka' tertentu karena yang ditanyakan adalah jumlah ((Rahardi, 2016)

\section{b. Maksim Kuantitas}

Berkaitan dengan maksim kuantitas, yakni yang menunjukkan bahwa penyampaian yang berpanjang-panjang itu hanya merupakan bukti dari sebuah ketidakefesienan pemakaian bentuk-bentuk kebahasaan. Dalam konteks pemakaian yang demikian, tentu bentuk kebahasaan dipersoalkan. Akan tetapi, kalau tujuannya adalah semata-mata memberikan informasi (giving information), bentuk kebahasaan seperti yang ditunjukkan itu harus dikatakan sebagai tuturan yang tidak efektif dan melanggar maksim kuantitas. Fakta kebahasaan itu juga dapat dikatakan sebagai melanggar prinsip kerja sama karena tidak memenuhi maksim kuantitas yang menggariskannya (Rahardi, 2016)

\section{c. Maksim Relevansi}

Dengan maksim relevansi, ketika terjadi proses komunikasi muka harus relevan atau berkaitan dengan yang sedang dibicarakan dengan mitra tutur. Dalam maksim ini maksim kerja sama akan nampak jika masing-masing pihak perlu memberikan kontribusi yang relevan dengan sesuatu yang sedang dipertuturkan. Jika hal tersebut tidak terjadi, tentu dalam komunikasi tersebut akan dianggap tidak memenuhi maksim relevansi dan sekaligus melanggar prinsip kerja sama Grice.

\section{d. Maksim Pelaksanaan atau Cara}

Ketika berkomunikasi dengan orang lain di samping harus ada masalah yang dibicarakan, juga harus memperhatikan bagaimana cara menyampaikannya. Kadang-kadang ada penutur ketika berkomunikasi, sebenarnya pokok masalah yang dibicarakan sangat bagus dan cukup menarik, namun jika cara 
penyampaiannya justru menyinggung perasaan, terkesan menggurui, kata-kata yang digunakan terasa kasar, atau cenderung melecehkan agar penutur saat berkomunikasi dengan mitra tutur. Kadang-kadang ada penutur ketika berkomunikasi, sebenarnya pokok masalah yang dibicarakan sangat bagus dan cukup menarik, namun jika cara penyampaiannya justru menyinggung perasaan, terkesan menggurui, kata-kata yang digunakan terasa kasar, atau cenderung melecehkan agar penutur saat berkomunikasi dengan penutur perlu memperhatikan hal-hal sebagai berikut:

1) Penutur harus mampu menjaga martabat mitra tutur saat berkomunikasi agar mitra tutur merasa tidak dipermalukan, dalam sebuahpernyataan, "Jika anda berbicara jaga jaraklah, karena bau mulutmu terasa." Tentu tuturan tersebut sangat menyinggung perasaan mitra tutur, karena itu penutur telah berbuat tidak santun kepada mitra tutur.

2) Penutur tidak boleh mengatakan halhal yang kurang baik mengenai diri mitra tutur (baik berupa orang atau barang yang ada kaitannya dengan mitra tutur). Misalnya dalam tuturan, "Tampaknya ayahmu tertangkap oleh Polisi karena kepadatan terjadi." Tentu tuturan tersebut tidak santun, apabila tuturan tersebut diubah dengan, "Tampaknya keluargamu mendapat cobaan, sabar ya semog ada hikmah di balik peristiwa itu." Penutur tidak boleh mengungkapkan rasa senang atau kemalangan mitra tutur. Perhatikan tuturan yang berbunyi, "Saya ikut bersyukur karena Anda selamat dalam kecelakaan itu, walaupun Anda harus kehilangan orang tua dalam peristiwa itu." Tuturan tersebut tidak santun karena penutur merasa ikut senang atas musibah yang dialami oleh mitra tutur. Jika ingin santun ubahlah tuturan itu menjadi, "Saya ikut berduka atas musibah yang Anda alami, semoga Anda tabah mengahadapinya."

3) Penutur tidak boleh menyatakan ketidaksetujuan secara langsung dengan mitra tutur hingga mitra tutur merasa jatuh harga dirinya. Dalam tuturan yang berbunyi, "Tujuan Anda apa, mengapa setiap Anda berbicara selalu memojokkan saya di hadapan banyak orang." Tergolong tidak santun dan sangat emosional. Mungkin saja keluhan penutur di atas ada benarnya, namun akan menjadi santun jika penutur mengatakan, "Saya mohon jika Anda menegur saya jangan di muka orang banyak, saya lebih senang dipanggil dan berbicara empat mata."

4) Penutur tidak boleh memuji diri sendiri atau membanggakan diri sendiri secara berlebihan. Sifat sombong pasti mempengaruhi kesantunan berbahasa. Mungkin apa yang dikatakan benar, tetapi karena menyangkut dirinya maka tuturan itu menjadi terkesan sombong dan tidak santun. Misalnya, "Saya cukup puas dalam diskusi kemarin, setiap saya berbicara mendapat sambutan hangat dan tepuk tangan yang meriah dari semua peserta." Tuturan tersebut terkesan seakan pembicara lain tidak sehebat dirinya. Sesungguhnya apa yang dikatakan itu hal yang biasa, tetapi karena menyangkut dirinya akhirnya terkesan sombong (Nurjamily, 2015)

Dalam penelitian ini peneliti akan meneliti tentang prinsip kerja sama Grice dalam talk show Hitam Putih "Pahlawan Veteran Indoneisa". Menganalisis pemakaian kerja sama Grice dalam acara tersebut. Yang akan dianalisis adalah kepatuhan penggunaan maksim kualitas, maksim kuantitas, maksim relevansi, maksim cara. Berikut penerapan prinsip Kerja Sama Grice alam acara talk show Hitam Putih "Pahlawan Veteran Indonesia"

(a) Anu: Makannya gak sekarang? Makannya?

Jesica: Makannya entar.

Deddy: Makannya nanti.

Dalam percakapan di atas penutur dan kawan tutur tidak melanggar maksim kualitas, kauntitas, relevan, dan cara, karena di dalam percakapan tersebut tidak ada unsur melebihlebihkan sesuatu pembicaraan atau tidak berbicara hal yang tidak perlu. Percakapan tersebut juga tidak memiliki adanya unsur berbohong (kualitas), unsur relasi (tidak keluar dari konteks). Cara penyampaian penutur dan kawan tutur pun tidak sulit untuk dipahami.

Konteks: Anu sedang berbicara bersama Deddy dan Jesica, di atas meja tempat mereka duduk sudah disediakan makanan yang banyak 
untuk para bintang tamu. Anu menanyakan apakah makanan ini bisa di makan sekarang, Deddy dan Jesica menjawab nanti, karena acara tersebut juga baru di mulai.

Jarak sosial: Jarak sosial antara Deddy, Jesica, dan Anu terbilang dekat, karena mereka sudah terbiasa membawa acara bersama. Dalam acara tersebut pun Deddy, Jesica, dan Anu bekerja sama, maka dari itu jarak sosial antara mereka terbilang dekat.

Jarak budaya: Faktor budaya penting saat berbicara. Percakapan di atas membuktikan bahwa budaya yang seharusnya Jesica berbicara sopan pada Deddy, karena mereka dekat maka tidak ada konteks budaya di dalam percakapan tersebut.

(b) Deddy: Apa kabar Bapak?

Veteran (Abdurrachman): Alhamdulillah

Baik.

Dalam percakapan di atas penutur dan kawan tutur tidak melanggar maksim kualitas, kuantitas, relevan, dan cara, karena di dalam percakapan diatas tidak ada unsur melebihlebihkan sesuatu pembicaraan atau tidak berbicara hal yang tidak perlu. Percakapan tersebut juga tidak memiliki adanya unsur berbohong dari penutur atau kawan tutur (kualitas), unsur relasi (tidak keluar dari konteks). Cara penyampaian penutur dan kawan tutur pun tidak sulit untuk dipahami.

Konteks: Deddy sedang menanyakan bagaimana kabar dari salah satu kakek veteran yang akan diajak berbicara oleh Deddy. Dan kakek tersebut menjawab dengan jawaban "Alhamdulillah baik".

Jarak sosial: Jarak sosial antara penutur dan kawan tutur terbilang jauh, karena itu kali pertama Deddy bertemu dengan para veteran. Melihat jarak sosial yang jauh Deddy berbicara dengan kakek dengan bahasa yang sopan, berbeda saat berbicara dengan Jesica.

Jarak budaya: Dilihat dari percakapan di atas budaya berbicara sopan dari yang muda ke tua dipakai dalam percakapan tersebut. Cara berbicara Deddy ke Kakek sangat sopan, itu membuktikan bahwa budaya berbicara sopan pada yang lebih diterapkan pada percakapan di atas. (c) Deddy: Oke. Nah, dari dua juta dua ratus ribu itu. Jujur nih apakah itu cukup?

Veteran (Abdurrachman): Ya kalau menurut, saya ya engga cukup si sebetulnya. Tapi kalau memang dipaksa ya mau gak mau, cukup gak cukup.

Dalam percakapan di atas tidak melanggar maksim kualitas, kuantitas, relevan, dan cara. Karena, di dalam percakapan tersebut tidak ada unsur melebih-lebihkan sesuatu atau tidak berbicara hal yang tidak perlu. Percakapan tersebut juga tidak memiliki adanya unsur berbohong (kualitas) atau unsur relasi (tidak keluar dari konteks). Cara penyampaian penutur dan kawan tutur pun tidak sulit untuk dipahami.

Konteks: Dalam percakapan tersebut sedang membicarakan tentang pensiunan para veteran yang didapatkan dari pemerintah. Deddy bertanya apakah cukup uang pensiun yang didapatkan kakek untuk kehidupan sehari-hari dan kakek menjawab ya cukup engga cukup. Dari jawaban tersebut maka secara tidak langsung kakek menjawab bahwa pensiun dengan jumlah dua juta dua ratus ribu tidak cukup, tapi mau bagaimana lagi, pensiun yang di dapat hanya dua juta dua ratus ribu dari pemerintah.

Jarak sosial: Jarak sosial antara kakek dan Deddy terbilang jauh. Maka dari itu penutur dan kawan tutur berbicara secara formal. Terlihat dari pertanyaan Deddy kepada kakek, itu membuktikan bahwa jarak sosial antara penutur dan kawan tutur jauh.

Jarak budaya: Budaya berbicara kepada yang lebih tua diterapkan dalam percakapan tersebut. Terbukti saat Deddy menanyakan masalah pendapatan para veteran dari pemerintah, Deddy sangat berhati-hati saat ingin melontarkan pertanyaan tersebut.

(d)Deddy: Jadi untung di sana ya. Oke. Ee gimana menurut kakek sendiri sebenarnya bagaimana rasanya kok hanya diberikan segitu uang pesangonnya?

Veteran (Abdurrachman): Iya, habis apa adanya Pak. Ya pengen banyak tapi apa adanya segitu, gak bisa berbuat apa-apa pak. 
Dalam percakapan di atas tidak melanggar maksim kualitas, kuantitas, relevan, dan cara. Karena, di dalam percakapan tersebut tidak ada unsur melebih-lebihkan sesuatu atau tidak berbicara hal yang tidak perlu. Percakapan tersebut juga tidak memiliki adanya unsur berbohong (kualitas) atau unsur relasi (tidak keluar dari konteks). Cara penyampaian penutur ke kawan tutur pun tidak sulit untuk dipahami.

Konteks: Pembicaraan di atas sedang membicarakan tentang pendapatan pesangon dari pemerintah untuk para veteran, Deddy yang terkejut karena pesangon yang didapatkan oleh para veteran dari pemerintah tidak sebanding dengan apa yang para veteran lakukan dulu. Dan kakek veteran pun pasrah dengan pesangon yang diberikan oleh pemerintah dengan jumlah yang menurut kakek sendiri pun tidak cukup.

Jarak sosial: Jarak sosial antara penutur dan kawan tutur terbilang jauh, maka dari itu penutur berbicara dengan nada sopan saat berbicara dengan kawan tutur.

Jarak budaya: Budaya yang dipakai dalam percakapan tersebut dipakai dengan baik. Terbukti saat Deddy bertanya dengan sopan pada kakek veteran. Budaya berbicara sopan pada yang lebih tua.

(e) Deddy: Oke baik, boleh tau Kek ini kakinya kenapa Kek pada saat itu?

Veteran (Abdurrachman): Ini kaki saya kena landasan pesawat.Dalam percakapan di atas tidak melanggar maksim kualitas, kuantitas, relevan, dan cara. Karena, di dalam percakapan tersebut tidak terdapat unsur melebih-lebihkan sesuatu atau tidak berbicara hal yang tidak penting. Percakapan tersebut juga tidak memiliki adanya unsur kebohongan (kualitas) atau unsur relasi (keluar dari konteks). Cara penyampaian penutur ke kawan tutur pun tidak rumit untuk dipahami.

Konteks: Deddy sedang bertanya kepada kakek, kenapa kaki kakek bisa cacat sebelah, dan kakek menjawab kaki tersebut cacat karena kena landasan pesawat saat kakek sedang membuat bandara pada waktu itu.
Jarak sosial: Jarak sosial antara penutur dan kawan tutur terbilang jauh, terbukti saat kawan tutur menyebut dirinya dengan sebutan saya.

Jarak budaya: Budaya yang telah kita pelajari adalah yang muda menghargai yang lebih tua. Di dalam percakapan tersebut budaya yang dipakai penutur sangat baik, karena penutur berbicara dengan kawan tutur dengan sangat sopan, melihat usia kawan tutur lebih tua dari pada penutur.

(f) Deddy: Usia kakek sekarang berapa?

Veteran (Abdurrachman): Usia saya 86.

Dalam percakapan di atas tidak melanggar maksim kualitas, kuantitas, relevan, dan cara. Karena, di dalam percakapan tersebut tidak melebih-lebihkan sesuatu atau tidak berbicara hal yang tidak perlu. Percakapan tersebut juga tidak memiliki adanya unsur berbohong (kualitas) atau unsur relasi (keluar dari konteks). Cara penyampaian penutur ke kawan tutur pun tidak sulit untuk dipahami.

Konteks: Penutur menanyakan usia kawan tutur saat kawan tutur telah banyak bercerita tentang pengalamannya waktu jaman perang dulu.

Jarak sosial: Jarak sosial antara penutur dan kawan tutur terbilang jauh. Terbukti saat kawan tutur menyebut dirinya dengan sebutan saya.

Jarak budaya: Budaya yang telah dipelajari adalah yang muda berbicara sopan atau bersikap sopan pada yang lebih tua. Dan budaya yang dipakai penutur untuk kawan tutur sangat baik, penutur dapat menghargai kawan tutur yang usianya jauh lebih tua dari pada penutur.

(g) Deddy: Lah gimana ini tugas menjadi matamata, gimana Nek?

Veteran (Siti Aminah): Jadi ee ke kota dan juga mengawasi karena tidak dicurigai, karena anak kecil gitu. Jadi untuk mengawasi berapa di tempat ee keadaan markas-markas itu.

Dalam percakapan di atas tidak melanggar maksim, kualitas, kuantitas, relevan, dan cara. Karena, tidak ada unsur melebih-lebihkan sesuatu atau tidak berbicara hal yang tidak perlu. Percakapan tersebut juga tidak memiliki adanya unsur kebohongan (kualitas) atau unsur 
relasi (keluar dari konteks pembicaraan). Cara penyampaian penutur ke kawan tutur pun tidak sulit untuk dipahami.

Konteks: Penutur sedang menanyakan kepada kawan tutur bagaimana tugas menjadi mata-mata pada jaman peperangan. Pada jaman peperangan untuk menjadi mata-mata tidak melihat umur, justru umur muda untuk menjadi mata-mata tidak begitu nampak, karena dianggap umur muda tidak bisa apa-apa. Namun, yang dilakukan oleh para veteran justru menggunakan anak kecil untuk menjadi matamata agar tidak dicurigai oleh bangsa lain.

Jarak sosial: Jarak sosial penutur dan kawan tutur terbilang jauh, karena kawan tutur adalah seorang veteran. Terbukti juga saat penutur memanggil kawan tutur dengan sebutan Nenek, itu membuktikan bahwa kawan tutur jauh lebih tua dibandingkan dengan penutur, yaitu Deddy Combuzier.

Jarak Budaya: Budaya yang diajarkan oleh bangsa Indonesia adalah yang muda menghormati ke yang lebih tua. Dan dari percakapan di atas membuktikan bahwa budaya tersebut dipakai oleh penutur kepada kawan tutur. Melihat usia kawan tutur yang lebih tua dari pada penutur.

(h) Deddy: Ow bawa pulang dua piala?

Reza Rahadian: Iya, untuk music dan actor dua-duanya dari film Rudi Habibie.

Deddy: Iya, tapi katanya gue denger katanya awalnya ee elu gak percaya gitu?

Reza Rahadian: Iya, gak tau soalnya jadi cuma sempet dikasih tau soal ada nominasi tersebut, tapi kemudia gak pernah ada omongan-omongan lagi, terus lagi syuting tiba-tiba di whatsapp masuk, terus ada foto pialanya selamat menang, jadinya kaya ah kenapa ya.

Dalam percakapan di atas tidak melanggar maksim kualitas, kuantitas, relevan, cara. Karena, di dalam percakapan tersebut tidak adanya unsur melebih-lebihkan percakapan apapun yang tidak perlu. Percakapan di atas juga tidak berbicara halyang memiliki unsur berbohong (kualitas) atau unsur relasi (keluar dari konteks pembicaraan). Cara penyampaian penutur dan kawan tutur pun tidak sulit untuk dipahami.

Konteks: Penutur dan kawan tutur sedang berbicara tentang penghargaan yang diterima oleh kawan tutur (Reza Rahadian) saat acara Best Actor di Asia Pasific Film Festival 2017. Kawan tutur memenangkan nominasi tersebut, namun kawan tutur tidak mengetahui bahwa diirinya akan menang pada nominasi itu, dan juga saat kawan tutur mengetahui bahwa namanya masuk dalam nominasi, dirinya sedang sibuk syuting untuk film terbarunya.

Jarak sosial: Jarak sosial antara penutur dan kawan tutur terbilang dekat. Karena, penutur bertanya kepada kawan tutur lebih santai dan kawan tutur pun menyebut dirinya dengan sebutan gue. Itu membuktikan bahwa penutur dan kawan tutur memiliki jarak sosial yang dekat.

Jarak budaya: Jarak budaya pada percakapan di atas juga tidak begitu dipermasalahkan. Karena, penutur dan kawan tutur sudah saling kenal, jadi budaya yang seharusnya kawan tutur berbicara lebih sopan kepada penutur tidak dipakai dalam percakapan antara penutur dan kawan tutur.

Pada data yang sudah diambil yang telah dianalisis di atas, dapat melihat bahwa acara talk show Hitam Putih yang dibawakan oleh Deddy Combuzier dan kawan-kawan, ada banyak sekali percakapan yang menggunakan prinsip Kerja Sama Grice.

\section{KESIMPULAN}

Berdasarkan penilitian di atas dapat disimpulkan bahwa acara talk show Hitam Putih "Pahlawan Veteran Indonesia" banyak menerapkan prinsip Kerja Sama Grice di dalam percakapannya, di mana di dalam Prinsip Kerja Sama Grice terdapat maksim kualitas, maksim kuantitas, maksim relevan/relasi, dan maksim cara. Selain mencari tuturan yang tidak melanggar prinsip kerja sama Grice, di dalam penelitian di atas pun mengaitkan percakapan percakapan dengan Jarak sosial dan jarak budaya. 


\section{REFERENSI}

Chaer, A. (2009). Pengantar Semantik Bahasa Indonesia. In Reneka Cipta (p. 280). Reneka Cipta.

Cliford, G. (1989). Abangan, Santri, Priyayi. In Pustaka Jaya (p. 200). Pustaka Jaya.

Damayanti, R. (2018). Diksi Dan Gaya Bahasa Dalam Media Sosial Instagram. Widyaloka IKIP Widya Darma, 5(3), 261-278.

Fatimah, F. N., Purnamasari, D., Pratiwi, D., \& Firmansyah, D. (2018). Analisis Kesalahan Berbahasa Pada Tuturan Pembawa Acara Dan Bintang Tamu Dalam Talk Show Hitam Putih Yang Berjudul. Parole, 1(5), 775-786.

Manab, A. (2015). Penelitian Pendidikan Pendekatan Kualitatif. In Kalimedia (p. 360). KALIMEDIA.

Nurjamily, W. O. (2015). Kesantunan Berbahasa Indonesia dalam Lingkungan Keluarga (Kajian Sosiopragmatik). Jurnal Humanika, $3(1), 1-18$.

Rahardi, K. (2016). Pragmatik Fenomena Ketidaksantunan Berbahasa. In Erlangga (p. 230). Erlangga.

Sauri, S. (2002). Pengembangan Strategi Pendidikan Berbahasa Santun di Sekolah. In Mimbar Pendidikan (Vol. 22, Issue 1).

Suryalaga, H. (2009). Kesundaan Rawalan Jati. In Yayasan Nur Hidayah (p. 190). Yayasan Nur Hidayah.

Wijana, I. D. P. (1996). Dasar-Dasar Pragmatik. In Andi (p. 240). Andi.

Wulandari, I. Y. (2016). Ragam Bahasa dalam Acara Talk Show Kick Andy Periode Mei 2015 dan Implikasinya dalam Pembelajaran Bahasa Indonesia di SMA. In Universitas Lampung. Universitas Lampung. 